Н. М. Шарманова

\title{
МОВНІ КЛІШЕ: З ІСТОРІЇ ВИВЧЕННЯ В ЛІНГВІСТИЧНІЙ ТРАДИЦІЇ
}

Шарманова Н. М. Мовні кліше: з історії вивчення в лінгвістичній традиції.

У статті висвітлюються питання щодо історії дослідження у вітчизняній i зарубіжній лінгвістиці проблематики мовних кліше як регулярних стандартизованих стереотипних лінгвем.

Ключові слова: мовне кліше, штамп, стереотип, теорія кліше.

Шарманова Н. Н. Языковые клише: из истории изучения в лингвистической традиции.

В статье освещены вопросы истории изучения в отечественной и зарубежной лингвистике проблематики языковых клише как регулярных стандартизированных стереотипных лингвистических единиц.

Ключевые слова: языковое клише, штамп, стереотип, теория клише.

Sharmanova N. M. Language clichés in relation to the history of the investigation in language tradition.

The article deals with questions of the history of the investigation of language cliché problems as regular standardized stereotype linguistic units both in Ukrainian and foreign linguistics.

Key words: language cliché, stock phrase, stereotype, cliché theory.

Дослідження мовної діяльності людини в сучасній науці уможливлюється різними аспектами, оскільки “насправді мову можна розглядати тільки як усю сукупність актів мовної діяльності” [8]. Найбільш оптимальним i вагомим для осмислення низки сучасних теоретичних проблем та розв'язання прикладних питань вітчизняного мовознавства $є$ історичний зріз, становлення проблематики дослідження різних мовних одиниць, навколо яких тривають наукові дискусії.

До таких одиниць належать мовні кліше - регулярні (постійні) комбінації словесних знаків, які $€$ автономними лінгвістичними утвореннями із заданими за традицією значенням і формою: Спочатку було слово (Свангеліє / заголовок інтерв'ю з В. Ф. Януковичем, “Вікна”, канал СТБ, 17.10.2008); Ona-ona! Америка - Свроna! (складова дитячої лічилки / реклама послуги «Улюблена країна» оператора мобільного зв’язку «Beeline»).

Мета статті полягає у висвітленні історії дослідження мовних кліше у вітчизняній i зарубіжній лінгвістиці. Мета розвідки передбачає розв'язання таких завдань: 1) розкриття стану розроблення питання про функціонування кліше як одного 3 малодосліджених аспектів українського мовознавства; 2) з'ясування історичних підходів вивчення в зарубіжному мовознавстві проблематики кліше.

Вивчення мовних кліше не належить сьогодні до кола найбільш розроблених проблем вітчизняного й зарубіжного мовознавства. Різні 
підходи до тлумачення мовної природи кліше пояснюються традиційним та інноваційним розумінням сутності цієї лінгвоодиниці. Усталеним у мовознавчій літературі $є$ погляд на кліше як стандартизовану мовну одиницю, пов'язану передусім 3 процесами стандартизації та фразеологізації мови офіційно-ділового стилю. Суто клішованими одиницями вважає „ділові” вислови разом із прислів'ями, приказками, афоризмами Г. Л. Пермяков - автор загальнотеоретичної проблеми клішування мовних одиниць - та зараховує їх до одного класу одиниць, що становлять завершене речення [12]. Ділові вислови разом з усталеними відтворюваними мовними одиницями вітчизняні й зарубіжні мовознавці відносять до фразеологічних одиниць за широкого розуміння об'єкта фразеології (В. В. Виноградов, О. В. Кунін, О. Д. Райхштейн, Л. Г. Скрипник, Г. М. Удовиченко, В. Д. Ужченко та ін.).

Проте жодна словникова стаття 3 дефініцією “кліше" не відсилає до поняття фраземи. При підготовці лексикографічного опису фразеологізму в Лінгвістичному енциклопедичному словнику В. М. Телія зазначає: "У сучасному зарубіжному мовознавстві усталені вислови розглядають як стилістичні засоби, фігури мови або штампи” [17, с. 559].

У вітчизняному мовознавстві теоретичні засади вивчення відтворювання мовних одиниць заклав О. О. Потебня. Однією з перших наукових розвідок щодо функціонування газетного штампу в публіцистичному стилі $є$ праця А. О. Борковського “О хибах нашой письменной мов'ъ”, опублікована 1886 року в часописі “Зоря”. Питаннями побутування в українській мові усталених ділових висловів у діахронічному й синхронічному аспектах займалися вітчизняні мовознавці Інституту української наукової мови, зокрема О. Б. Курило, М. Я. Калинович. У 1928 році М. Д. Гладкий видає статтю, присвячену особливостям використання фразеологізованих сполук у публіцистичному стилі [6]. У тому ж році виходить друком праця «У пильній справі», де розглядається побутування штампів у мові публіцистики [15].

Поясненням гострої потреби систематизації української ділової фразеології на противагу мовним „штампам” російської мови позначено вихід друком у 1927 році „Російсько-українського словника ділової мови”, який уклали В. Підмогильний i $\mathcal{~}$. Плужник. Зусиллями І. Огієнка протягом 1933-1938 років у щомісячному часописі „Рідна мова” у Варшаві видається низка публікацій під рубриками „Українська канцелярійна мова”, „Словник чужих слів”, де наголошувалося на невиправданому вживанні калькованих висловів 3 польської, російської мов у різних стильових різновидах української мови.

М. А. Жовтобрюх, вивчаючи мову преси початку XX ст., здійснює всебічний опис усіх властивих тому часу тенденцій, що мали вплив на розбудову української публіцистики. Протягом 1962-1968 років точилася тривала дискусія на сторінках наукових часописів „Мовознавство”, „Вестник 
Московского университета, „Русская речь” щодо функціонування штампів у мові преси. У низці наукових розвідок звернена увага вітчизняних дослідників на ці питанні (Н. О. Бойченко, В. М. Кибальчич, О. Покровська, О. А. Сербенська, О. С. Снітко, Н. І. Швидка).

Наслідком наукової дискусії на сторінках фахових періодичних видань стало те, що в науковій літературі дефініції „штамп” і „кліше” набули виразного негативного забарвлення. Найчастіше їхній ужиток обмежується офіційно-діловою сферою спілкування. Питання щодо побутування кліше в мові, і зокрема в офіційно-діловому стилі, стало предметом наукового зацікавлення Н. Д. Бабич, С. П. Бибик, М. А. Жовтобрюха, С. Я. Єрмоленко, А. П. Коваль, Л. І. Мацько, О. Д. Пономарева, Н. М. Сологуб та ін. У їхніх роботах наявне апелювання до таких понять, як: “канцелярський вислів-кліше" (Н. М. Сологуб), “канцелярський зворот” (М. А. Жовтобрюх), „мовна формула” (Л. І. Мацько), “мовна формула-штамп” (М. М. Пещак) та інших дефініцій на кшталт "канцелярський шаблон” (А. Ф. Марахова), “стійке сполучення слів" (Д. Горбачук, Л. Коваленко), “стандартизоване словосполучення" (Р. Ф. Возна) тощо [3, с. 267-278]. Протягом останніх десятиріч у вітчизняному мовознавстві укладено лексикографічні праці, у яких під маркування сталого вислову відведено різнорівневі мовні одиниці [5; 7].

У вітчизняному мовознавстві для з'ясування мовної специфіки кліше існують векторні тлумачення: від традиційного, з негативним маркуванням як шаблонної фрази, “заяложеного виразу” [4, с. 546] до протилежного - як мовного стереотипу з позитивною функцією, конструктивної одиниці мови $[14$, c. 237]. У термінологічних працях останніх років подано тлумачення дефініції “кліше", під яким розуміють стандартні відтворювані засоби мови, які регулярно повторюються в певних контекстах і служать ознаками певного стилю або акту комунікації [13, с. 209].

У сучасному зарубіжному мовознавстві питання про сутність поняття кліше та побутування його в мові стали предметом розгляду в працях В. В. Гвоздєва, Т. М. Дрідзе, В. В. Красних, О. С. Кубрякової, Ю. Є. Прохорова, О. Н. Саввіної, Ю. А. Сорокіна, Р. Ратмайр, О. І. Шейгал. У професійній діяльності (у сферах бізнесу, сервісу тощо) специфіку використання кліше в діловому спілкуванні розкрили Н. О. Богатирьова, А. Д. Баришева, 3. І. Гур'єва, Ю. О. Матюхіна, О. В. Солякін та інші науковці. У процесі дослідження особливостей російської документної лінгвістики С. П. Кушнерук важливе місце у структуруванні ділового тексту відводить саме мовному кліше. Функціонування кліше в наукових текстах на матеріалі авторефератів кандидатських дисертацій з філології та педагогіки дослідила Н. О. Ведякова. Мовні кліше в окресленні моделей щоденної комунікації, індивідуального розмовного стилю розкривають Л. В. Кноріна, Т. М. Ніколаєва. Кліше як засіб мовної гри в етикетній мовній поведінці міських мешканців описано в роботі В. В. Блажес. Крім 
того, на матеріалі російської мови клішовані формули в периферийних текстах розкриває М. П. Котюрова.

В останні десятиріччя незаперечним $є$ посилення інтересу лінгвістів до питань функціонування готових, усталених мовних комплексів у різних мовах. Таке зацікавлення пояснюється домінуванням у наукових працях численних підходів до опису мовних фактів, серед яких центральне місце посідає функціональний підхід. У монографії Н. Ф. Баландіної „Функції і значення чеських прагматичних кліше в комунікативному контексті" подано аналіз чеських прагматичних кліше як міжрівневих одиниць, значення і функції яких сформовано мовною системою та визначено процесом спілкування [1].

У славістиці питання трансформації мовних кліше як засобів комунікативного впливу в мові російських ЗМІ дослідила М. Муратова. У світлі стереотипізації свідомості маніпулятивний потенціал ідеологічних мовних кліше представлено в Г. А. Копніної. У сучасному зарубіжному мовознавстві зазначену специфіку мовних кліше на семантичному, лексичному і граматичному рівнях та реалізацію їх у діалогічному мовленні на матеріалі французької мови дослідили М. К. Сабанєєва, О. В. Шамрай, С. Ф. Фоміна. Французькі мовні кліше розмовного стилю в комунікативно-прагматичному аспекті розкриває А. В. Власова. Метакомунікативні функції мовних кліше англійської мови стали предметом лінгвістичного аналізу в працях В. В. Стрибижева. Англійські комунікативні кліше в аспекті основних напрямків контекстних прагмалінгвістичних досліджень представлено в роботах Т. П. Третьякової. На матеріалі французької та англійської мов дослідження мовної природи і функціонування кліше проведено В. В. Бурунським. На матеріалі німецької мови проблематика кліше репрезентована в розвідках Д. Г. Мальцевої. Укладач універсального довідника "Німецька мова. Gutes deutsch in schrift und rede" Л. Маккензен серед готових блоків слів і зворотів мови розглядає три різновиди клішованих одиниць: 1) кліше як окрасу мови (Formeln als Redeschmuck); 2) кліше, яких потрібно уникати у процесі комунікації (Formeln, die man vermeiden soll); 3) закостенілі кліше (Erstarrte Formeln) $[10$, c. $152-164]$.

Цікавими 3 наукового погляду щодо сутності мовного кліше $є$ положення семантики мови. М. А. Кронгауз говорить, що в сучасній лінгвістиці поняття “мовне кліше" не зовсім визначене. Під ним розуміють i фразеологізми, і просто частотні поєднання, а також більш складні семантичні єдності: стандартні репліки, гасла, популярні цитати та багато іншого" [9, с. 57]. У процесі дослідження семіотичної сутності та логікосеміотичного моделювання мовних одиниць російський дослідник М. А. Черкаський наголошує на тому, що для всіх усталених відтворюваних мовних одиниць притаманні ознаки клімованості властивість мовної одиниці сприйматися глобально, як конструктивне й 
семантичне ціле, що відтворюється без істотних змін у певних комунікативних ситуаціях [16, с. 36].

Диференціація кліше на замкнені й незамкнені виявилася в подальших лінгвістичних дослідженнях досить продуктивною. Так, за замкненими кліше на сьогодні закріпилися назви: “прислівне кліше”, або “паремія як мовне кліше" (Н. І. Єфремова, О. Є. Жигаріна); "афористичне кліше" (О. Є. Шейгал). Незамкнені кліше, або "канцелярські кліше” (Т. Г. Винокур), традиційно розглядаються у формальному розумінні та в поєднанні зі штампами і стереотипами (різниця - у ступені відтворюваності й функціональному спрямуванні). Загалом же питання щодо ідентифікації мовного кліше є одним із дискусійних, що дозволяє зараховувати їх до перехідних явищ у системі лексики і фразеології [11].

Визначені вище погляди на мовну природу кліше, без сумніву, потребують уточнення висунутих положень і грунтовного вивчення цього багатоаспектного явища в контексті теорії кліше.

Отже, спираючись на наявні в мовознавчій традиції підходи щодо вивчення мовної природи кліше, розуміємо, що їх дослідження як лінгвоодиниць і водночас репрезентантів процесів комунікації дозволяє уточнити окремі теоретичні положення, зокрема поняття мовного значення, співвідношення різних рівнів у системі самої мови, лінгвостилістичні проблеми, номінативний аспект мовної одиниці, комунікативне i прагматичне призначення клішованих одиниць. Такий аналіз на перспективу дасть змогу дослідити роль мовних кліше у процесі їх використання реципієнтом при породженні та функціонуванні мови.

1. Баландіна Н. Ф. Функції i значення чеських прагматичних кліше в комунікативному контексті / Надія Францівна Баландіна / НАН України, Ін-т мовознавства ім. О. О. Потебні. - К. : АСМІ, 2002. - 332 с.

2. Бацевич Ф. С. Словник термінів міжкультурної комунікації / Флорій Сергійович Бацевич. - К. : Довіра, 2007. - 205 с.

3. Бибик С. П. Офіційно-діловий стиль / С. П. Бибик // Українська лінгвостилістика XX - початку XXI ст.: система понять і бібліографічні джерела / За ред. С. Я. Єрмоленко. - К., 2007. - С. 267-278.

4. Великий тлумачний словник сучасної української мови / Відп. ред. В.Т. Бусел. - К. : Ірпінь, ВТФ : Перун, 2007. - 1736 с.

5. Вирган I. О. Російсько-український словник сталих виразів / І. О. Вирган, М. М. Пилинська. - Х. : Прапор, 2009. - 864 с.

6. Гладкий М. Фразеологія газетної мови / М. Гладкий // Червона преса. - 1928. № 1. - С. 39-43; № 2. - С. 37-43.

7. Головащук С. І. Російсько-український словник сталих словосполучень / Сергій Іванович Головащук. - К. : Наук. думка, 2001. - 640 с.

8. Гумбольдт В. фон. Избранные труды по языкознанию / Вильгельм фон Гумбольдт / пер. под. ред. и с предисл. Г. В. Рамишвили. - М., 1984. - 400 с. 
9. Кронгауз М. А. Семантика: [учеб. для студ. лингв. фак. высш. учеб. заведений] / Максим Анисимович Кронгауз. - М., 1995. - 208 с.

10. Маккензен Л. Немецкий язык. Универсальный справочник / Лутц Маккензен; пер. с нем. Е. Захарова. - М. : Аквариум, ООО «Издательство АСТ-ЛТД», 1998. - 592 c.

11. Переходные явления в области лексики и фразеологии русского и других славянских языков (Вторые Жуковские чтения) : [материалы Междунар. научн. симпозиума]. / Отв. ред. В. И. Макаров. - Великий Новгород : Изд-во Новгородского гос. ун-та, 2001. - 209 с.

12. Пермяков Г.Л. Основы структурной паремиологии / Г. Л. Пермяков. - М. : Наука, 1988. - 224 с.

13. Селіванова О. О. Сучасна лінгвістика: термінологічна енциклопедія / О. О. Селіванова. - Полтава : Довкілля-К, 2006. - 716 с.

14. Українська мова. Енциклопедія. - К. : Укр. енциклопедія, 2000. - 752 с.

15. У пильній справі // Вісник Ін-ту укр. наук. мови. - 1928. - Вип. 1. - С. 84-85.

16. Черкасский М. А. Опыт построения функциональной модели одной частной семиотической системы (пословицы и афоризмы) / М. А. Черкасский // Паремиологический сборник: Пословица. Загадка. (Структура, смысл, текст). М., 1978. - С. 35-52.

17. Языкознание: Большой энциклопедический словарь / Гл. ред. В. Н. Ярцева. M., 2000. -688 c.

Стаття надійшла до редакиії 20.10.2010 p. 